\title{
PROBLEMATIKA PEMBERIAN SANKSI TERHADAP PENOLAKAN VAKSINASI COVID-19: SUATU KAJIAN PERSPEKTIF HAM
}

Hari Sutra Disemadi, Tomi Suhendra Pardede; Fakultas Hukum, Universitas Internasional Batam, Indonesia; Jl. Gajah Mada, Baloi Permai, Kec. Sekupang, Kota Batam, Kepulauan Riau; Email: hari@uib.ac.id

\begin{abstract}
Abstrak
Penelitian ini menggunakan jenis metode penelitian yuridis normative, bertujuan untuk mengkaji permasalahan terkait pemberian sanksi akibat penolakan vaksinasi terhadap hak asasi manusia untuk menolak pengobatan. Penyebaran epidemi Corona Virus Desease 2019 atau Covid-19 berkembang cukup pesat di Indonesia. Pemerintah Indonesia telah melakukan berbagai macam cara untuk menanggulangi penyebaran wabah Covid-19, contohnya karantina wilayah serta Pembatasan Sosial Berskala Besar. Memasuki awal tahun 2021 dimulai dengan masuknya vaksin Covid-19 ke Indonesia. Pemerintah menghimbau agar semua orang divaksin. Namun ternyata ada sanksi bagi orang yang menolak vaksinasi tersebut. Sanksi tersebut berupa sanksi pidana penjara maupun denda. Hal tersebut semakin dipertegas dengan dikeluarkannya peraturan mengenai penolakan vaksin. Pemberian sanksi ini masih menjadi isu hangat ditengah masyarakat apakah melanggar hak asasi manusia atau tidak karena setiap orang memiliki hak untuk menolak tindakan medis. Berdasarkan penelitian yang dilakukan, didapatkan hasil penelitian bahwa hukum di Indonesia belum sepenuhnya dapat memberikan kepastian hukum, perlindungan serta keadilan bagi warganya karena masih terdapat kerancuan hukum ataupun pertentangan diantara peraturan perundang-undangan itu sendiri.
\end{abstract}

Kata Kunci: Sanksi, Penolakan, Vaksinasi, Hak Asasi Manusia

\begin{abstract}
This study uses a normative juridical research method. The research conducted aims to examine problems related to the imposition of sanctions due to refusal of vaccination against human rights for refusing treatment. The spread of the Corona Virus Desease 2019 or Covid-19 epidemic is growing quite rapidly in Indonesia. The Indonesian government has taken various ways to tackle the spread of the Covid-19 outbreak, for example, regional quarantine and Large-Scale Social Restrictions. Entering the beginning of 2021, the Covid-19 vaccine entered Indonesia. The government calls on everyone to be vaccinated. However, it turns out that there are sanctions for people who refuse the vaccination. These sanctions are in the form of imprisonment and fines. This was further emphasized by the issuance of regulations regarding vaccine refusal. The imposition of sanctions is still a hot issue in the community whether it violates human rights or not because everyone has the right to refuse medical treatment. Based on the research conducted, it was found that the law in Indonesia has not been fully able to provide legal certainty, protection and justice for its citizens because there are still legal confusion or conflicts between the laws and regulations themselves.
\end{abstract}

Keywords: Sanctions, Refusal, Vaccination, Human Rights

\section{PENDAHULUAN}

\section{Latar Belakang}

Pada penghujung tahun 2019, dunia digemparkan dengan munculnya sebuah wabah virus yang kemudian dinamakan Covid-19. Covid-19 merupakan virus baru yang bersifat menular. Virus ini pertama kali diketahui muncul di Wuhan, China". ${ }^{1}$ Covid-19 ini ialah

\footnotetext{
1 Sari, M. K. (2020). "Sosialisasi tentang Pencegahan Covid-19 di Kalangan Siswa Sekolah Dasar di SD Minggiran 2 Kecamatan Papar Kabupaten Kediri". Jurnal Karya Abdi Masyarakat, 4(1), 80-83, h. 81.
} 
virus yang menyerang pernapasan manusia yang diakibatkan oleh novel corona virus atau SAR-Cov-2". ${ }^{2}$

Virus ini dapat menyebar dengan sangat cepat, melihat perkembangan angka penyebaran di awal pandemi hingga sekarang yang sangat besar. ${ }^{3}$ Gejala yang diketahui apabila seseorang terjangkit virus ini misalnya demam, sesak nafas, kelelahan, dan lainlain. Tingkat penyebaran virus yang sangat cepat ini membuat angka angka korban terjangkit virus maupun korban yang meninggal dunia akibat terjangkit virus tersebut berkembang sangat pesat. Berdasarkan data yang diperoleh dari website resmi Kementrian Kesehatan Republik Indonesia yang diakses tanggal 10 Februari 2021, dikonfirmasikan sebanyak 1.183.555 warga terinfeksi Covid-19 dan 32.167 diantaranya meninggal dunia. ${ }^{4}$

Dengan angka penyebaran yang kian meningkat, pemerintah pun mengambil beberapa tindakan untuk mencegah terjadinya peningkatan jumlah korban terjangkit virus tersebut. Kebijakan pertama kali yang dilakukan adalah wajib menggunakan masker serta wajib menjaga jarak satu dengan yang lain/social distancing. Kemudian muncul sistem Work from Home (WFH) dimana kita bisa melakukan pekerjaan yang biasanya di kantor, akan kita lakukan di rumah. ${ }^{5}$ Hal ini diterapkan tentunya dengan harapan untuk meminimalisir kemungkinan meningkatnya penyebaran virus. Namun kenyataannya penerapannya tidak berjalan dengan baik. Sudah menjadi rahasia umum bahwa adanya larangan untuk berkumpul disuatu tempat dan melakukan social distancing tidak diperhatikan dengan baik oleh masyarakat Indonesia. Kita sudah mendengar banyak kasus pelanggaran, misalnya tidak memakai masker, tidak menaati protokol kesehatan dan lain-lain hingga harus membayar denda karena melanggar aturan tersebut. ${ }^{6}$

Melihat tidak adanya perubahan yang signifikan, malah sebaliknya, pada akhir bulan Maret 2020, mulai terdengar isu bahwa akan diadakan karantina wilayah untuk menekan angka penyebaran virus Covid-19. Keputusan tersebut kemudian direalisasikan kedalam sebuah Peraturan Pemerintah/PP sebagai pelaksanaan dari UU no. 6 tahun 2018 tentang Kekarantinaan Kesehatan yang dalam penelitian ini akan disingkat menjadi UU Kekarantinaan Kesehatan. Kebijakan tersebut dituangkan bentuk peraturan sebagai contoh yaitu: Peraturan Wali Kota Medan No. 27 tahun 2020 tentang Pelaksanaan Adaptasi Kebiasaan Baru pada Kondisi Pandemi Corona Virus Desease 2019 (Covid-19) di Kota Medan. Contoh lainnya yaitu Perda DKI Jakarta No. 2 Tahun 2020 tentang

2 Sari, M. K. (2020). Loc.Cit.

3 Disemadi, H. S., \& Handika, D. O. (2020). "Community compliance with the covid-19 protocol hygiene policy in Klaten Regency, Indonesia". Legality: Jurnal Ilmiah Hukum, 28(2), 121-133., h.. 122.

${ }^{4}$ Kementerian Kesehatan Republik Indonesia. (2021). https://www.kemkes.go.id/, diakses pada tanggal 10 Februari 2021.

${ }^{5}$ Kang, C., \& Disemadi, H. S. (2021). The Covid-19 Pandemic Outbreak Impact And Prevention From Legal Perspective: An Indonesian Experience. In CoMBInES-Conference on Management, Business, Innovation, Education and Social Sciences. 1(1), 134-144)., h. 136.

${ }^{6}$ Appludnopsanji, A., \& Disemadi, H. S. (2020). "Problematika Kebijakan Pembebasan Narapidana sebagai Upaya Penanggulangan Covid-19 di Indonesia". Jurnal Wawasan Yuridika, 4(2), 131-148., h. 135. 
Penanggulangan Corona Virus Desease 2019. Kenyataannya langkah untuk menetapkan karantina tidak berjalan sebaik yang diharapkan. Tidak bisa dipungkiri bahwa tidak semua masyarakat taat akan aturan maupun protokol kesehatan sebagaimana peraturan maupun himbauan yang diterapkan oleh pemerintah. Pemerintah ditingkat pusat hingga pemerintah tingkat daerah pun menetapkan sanksi berupa denda bagi masyarakat yang tidak menaati protokol kesehatan tersebut. Pada umumnya sanksi diberikan bagi mereka yang melakukan aktivitasnya namun tidak menggunakan masker.

Lebih jauh, ternyata sanksi denda tidak hanya diberlakukan bagi mereka yang tidak menaati protokol kesehatan. Pada Pasal 29 jo Pasal 30 Perda DKI Jakarta No. 2 Tahun 2020 tentang Penanggulangan Covid-19 disebutkan bahwa penolakan secara sengaja terhadap tes cepat molekuler serta vaksinasi dapat diberikan sanksi, yaitu denda sebanyak Rp. 5.000 .000 (lima juta rupiah). Pemberian sanksi ini kemudian menjadi sorotan utama ditengah masyarakat.

Diketahui bahwa setiap orang mempunyai hak untuk memberikan "persetujuan" maupun "penolakan" sebelum dilakukannya pengobatan yang akan dilakukan oleh tenaga kesehatan terhadap dirinya. Keputusan seseorang untuk menolak tersebut biasanya dilakukan setelah orang tersebut menerima informasi terhadap penyakit yang dideritanya, sebagaimana tertuang didalam Universal Declaration of Human Rights (art. 19).7 Sebelum dilakukannya tindakan medik, seorang pasien terlebih dahulu harus menandatangani sebuah persetujuan yang biasa dikenal sebagai "Informed Consent" atau "Persetujuan Tindakan Medis" maupun "Informed Refusal" atau "Penolakan Tindakan Medis". 8

Berbicara mengenai hak, itu artinya kita tidak lepas dari pengakuan hak asasi manusia di Indonesia. Pancasila sendiri pada dasarnya adalah memegang teguh hak asasi manusia pada setiap silanya, lebih tepatnya dapat kita temukan dalam bunyi sila yang ke dua Pancasila yaitu: "kemanusiaan yang adil dan beradab". Jaminan kepastian hukum bagi hak asasi manusia khususnya setiap warga maupun penduduk di Indonesia tentunya membutuhkan payung hukum, legalitas serta pengakuan akan hak asasi manusia. Hal ini kemudian diatur dalam “Undang-Undang Nomor 39 Tahun 1999 tentang Hak Asasi Manusia". Sehubungan dengan perlindungan HAM terhadap seluruh warga negara Indonesia, dengan adanya ST tahun 2001 Majelis Permusyawaratan Rakyat (MPR) memutuskan untuk melakukan perubahan mengenai ketentuan ketentuan yang mengatur HAM dalam perubahan ketiga UUD 1945, sejalan adanya perubahan tersebut diharapkan agar semakin dihormati dan ditegakkannya hak asasi manusia di Indonesia. ${ }^{9}$

Adanya peraturan-peraturan yang tidak sejalan satu sama lainnya menimbulkan pertanyaan, hukum manakah yang harus kita patuhi. Di satu sisi, apabila kita menolak vaksinasi maka ada sanksi bagi yang menolaknya. Namun disisi lainnya, sebagai

7 Zulhasmar, E. (2008). “Implikasi Hukum Penolakan Tindakan Medik”. Lex Jurnalica Vol. 5 No. 2, 2008, 83-111, h. 91.

8 Zulhasmar, E. (2008). Ibid., h. 83-84.

${ }_{9}$ Arifin, R., \& Lestari, L. E. (2019). “Penegakan dan Perlindungan Hak Asasi Manusia di Indonesia dalam Konteks Implementasi Sila Kemanusiaan yang Adil dan Beradab". Jurnal Komunikasi Hukum (JKH), 5(2), 12-25, h. 15. 
manusia kita berhak untuk menolak hal tersebut. Hal-hal seperti inilah yang menjadi perdebatan di tengah masyarakat. Setelah mengetahui latar belakang permasalahan di atas, penelitian ini membahas lebih dalam mengenai problematika antara penerapan pemberian sanksi atas penolakan vaksinasi Covid-19 perpektif HAM.

\section{Rumusan Masalah}

Setelah mengetahui pemaparan latar belakang diatas, maka dapat dirumuskan permasalahan sebagai berikut:

1. Apakah penerapan pemberian sanksi bagi penolak vaksin Covid-19 melanggar hak asasi manusia?

2. Apakah pemberlakuan sanksi tersebut telah mencerminkan keadilan sebagaimana tertuang didalam Pancasila sebagai falsafah dan cita hukum bangsa Indonesia?

\section{METODE PENELITIAN}

Metode penelitian yang digunakan merupakan metode yuridis normatif dengan mengkaji data sekunder berupa bahan hukum. Bahan hukum kepustakaan yang berkaitan dengan peraturan hukum atau perundang-undangan (law in books) terkait topik penelitian penulis. Penelitian ini menggunakan teknik pengumpulan data secara studi kepustakaan, dimana seluruh data yang didapatkan melalui tulisan-tulisan, literatur maupun hukum tertulis berupa perundang-undangan. Beberapa perundangan yang digunakan sebagai bahan referensi dalam penelitian ini yakni Perda DKI Jakarta No. 2 Tahun 2020 tentang Penanggulangan Corona Virus Desease 2019; UU No. 39 Tahun 1999 tentang Hak Asasi Manusia; UU No. 6 Tahun 2018 tentang Kekarantinaan Kesehatan; UU No. 44 Tahun 2009 tentang Rumah Sakit; UU No. 4 Tahun 1984 tentang Wabah Penyakit Menular; UU No. 12 Tahun 2011 tentang Pembentukan Peraturan Perundang-Undangan; serta Universal Declaration of Human Rights (art. 19). Dalam penelitian ini pun menggunakan beberapa jenis pendekatan penelitian, diantaranya adalah dengan pendekatan perundang-undangan, pendekatan konseptual serta pendekatan perbandingan hukum.

\section{PEMBAHASAN}

Berbicara mengenai wabah virus yang sangat pesat perkembangannya dalam setahun terakhir, yaitu Corona Virus Desease 2019 (Covid-19) sampai saat ini masih menjadi tugas utama dalam penanggulangan wabah virus ini. Perkembangannya yang sangat pesat sangat mengkhawatirkan (Kemkes, 2020). Oleh karena itu, pemerintah mengambil langkah langkah untuk memperketat protokol kesehatan demi menghambat laju penyebaran virus ini. Untuk mengantisipasi ataupun menghambat perluasan virus Covid-19 yang semakin tidak terkontrol, pemerintah memberikan penyuluhan bersifat persuasif kepada seluruh masyarakat untuk melaksanakan protokol kesehatan untuk mencegah penularan virus seperti dengan melakukan "physical distancing", selalu memakai masker, menjaga kebersihan dengan mencuci tangan, menaikan tingkat kekebalan dan daya tahan tubuh serta menjaga kesehatan. ${ }^{10}$ Protokol ini tentu saja bermanfaat untuk mengetahui status dari seseorang apakah ia berstatus negative atau positif terpapar virus Covid-19.

${ }^{10}$ Sari, M. K. (2020). Loc. Cit. 
Di masa pandemi, keadaan ekonomi Indonesia menurun drastis. Penurunan ini sangat terasa bagi masyarakat golongan ekonomi menengah kebawah. Harga bahan pokok sempat melonjak naik akibat kepanikan warga yang membuat mereka memborong bahan pangan dalam jumlah yang besar sehingga menimbulkan kelangkaan. Tidak hanya bahan pangan, melainan para pedagang masker, baik perorangan maupun grosir serta supermarket memanfaatkan situasi ini dengan menaikkan harga masker setinggi tingginya. ${ }^{11}$ Keadaan ini seolah dijadikan sebagai kesempatan bagi oknum oknum seperti itu untuk meraup keuntungan sebesar besarnya. Bagaimana tidak, dengan situasi pandemi, kewajiban memakai masker serta kepanikan masyarakat membuat mereka mau tidak mau harus membeli masker, meskipun dengan harga yang sangat mahal. Harga satu kotak masker yang biasanya berkisar hanya puluhan ribu rupiah, bisa melonjak hingga ratusan bahkan jutaan ribu rupiah. Fenomena tersebut kemudian menjadi perhatian khususnya untuk pemerintah dalam menjaga kestabilan harga, serta menerapkan hukum dan sanksi bagi oknum oknum seperti yang telah disebutkan.

Pemerintah juga mulai menggunakan metode baru dalam bekerja, yaitu sistem kerja dari rumah (WFH). Orang yang melakukan aktifitas biasanya di kantor, sekarang mulai bekerja dari rumah demi mencegah penularan dari wabah virus ini. Tidak hanya itu, kerugian justru dialami karena pandemi ini. Yang terkena dampak kerugian tidak hanya pengusaha, tetapi para karyawan juga. Tak sedikit dari mereka yang diputuskan kontraknya oleh perusahaan dengan alasan efisiensi pekerja. Hal ini tentu menjadi permasalahan bagi masyarakat terutama yang kehilangan pekerjaannya. Demi membantu keadaan ekonomi dalam situasi ini, pemerintah meyalurkan bantuan berupa sembako maupun bantuan dana seperti bantuan langsung tunai. Tidak berhenti sampai disitu, menyikapi dunia pendidikan yang berubah dari tatap muka menjadi daring/online, pemerintah juga memberikan bantuan berupa kuota gratis bagi para pelajar.

\section{A. Pemberlakuan Sanksi terhadap Penolakan Vaksinasi Serta Kaitannya dengan Hak Asasi Manusia}

Memasuki tahun 2021, tepatnya pada bulan Januari vaksin Covid-19 masuk ke Indonesia. Pemerintah menyuarakan agar setiap orang divaksin, dan vaksin ini diberikan secara gratis. Bertahap mengenai pemberian vaksin ini, kemudian dikeluarkan dalam berbagai jenis peraturan mengenai penanggulangan Covid-19 dan kewajiban untuk divaksin. ${ }^{12}$ Perdebatan ditengah masyarakat kemudian timbul karena adanya informasi mula mula dari pemerintah bahwa apabila seseorang menolak pemberian vaksin tersebut, maka akan dikenakan sanksi berupa denda. Hal ini lantas diwujudkan, dapat kita temukan dalam Perda DKI Jakarta No. 2 Tahun 2020 Pasal 30 yang berbunyi "Setiap orang yang dengan sengaja menolak untuk dilakukan pengobatan dan/atau vaksinasi Covid-19, dipidana dengan pidana denda paling banyak sebesar Rp5.000.000,00 (lima juta

${ }^{11}$ Fransisco, W. (2020). “Interaktif Masyarakat terhadap Hukum Dalam Kehidupan Normal Baru Pasca Covid-19". Journal of Judicial Review, 22(2), 151-164., h. 152-153.

12 Masnun, M. A., Sulistyowati, E., \& Ronaboyd, I. (2021). "Pelindungan Hukum Atas Vaksin Covid-19 dan Tanggung Jawab Negara Pemenuhan Vaksin dalam Mewujudkan Negara Kesejahteraan". DiH: Jurnal Ilmu Hukum, 17(1), 35-47., h.. 37. 
rupiah)". Penggunaan frasa "setiap" dalam pasal ini artinya tidak ada diskriminasi ataupun penggolongan pihak mana saja yang melakukan penolakan, maka dikenakan sanksi menurut pasal tersebut. Sedangkan dalam UU Rumah Sakit pasal 32 huruf k disebutkan mengenai hak pasien dan dapat dipahami berdasarkan ketentuan tersebut bahwa "salah satu hak pasien adalah memberikan persetujuan atau menolak atas tindakan medis yang akan dilakukan oleh tenaga kesehatan terhadap penyakit yang dideritanya." Dapat disimpulkan dalam bahasa sederhananya adalah bahwa pasien berhak untuk menolak pengobatan (Hak pasien). ${ }^{13}$ Hal ini jelas bahwa sudah merupakan hak mendasar dalam segala tindakan medik yang akan dilakukan terhadap seseorang.

Perlu kita ketahui sebelumnya bahwa tempat pelayanan vaksinasi Covid-19 menurut keterangan dari Kementerian Kesehatan adalah: “1) Puskesmas, Puskesmas Pembantu; 2) Klinik; 3) Rumah Sakit dan/atau; 4) Unit Pelayanan Kesehatan di Kantor Kesehatan Pelabuhan (KKP)" (Kemkes, 2021). ${ }^{14}$ Lantas apakah semua orang yang diwajibkan untuk divaksin dapat dikategorikan sebagai pasien? Melihat pengertian pasien menurut salah satu ahli bernama Daldiyono yang menyatakan bahwa pasien merupakan setiap orang yang dengan kemauannya sendiri meminta bantuan kesehatan dari dokter, baik untuk sekedar konsultasi akan kesehatannya, maupun untuk melakukan pengobatan atas penyakit yang dideritanya, baik itu pskologis, fungsional maupun organik.. ${ }^{15}$ Sedangkan pengertian hukumnya, menurut UU No. 44 tahun 2009 tentang rumah sakit Pasal 1 angka 4, "pasien adalah setiap orang yang melakukan konsultasi masalah kesehatannya untuk memperoleh pelayanan kesehatan yang diperlukan, baik secara langsung maupun tidak langsung di Rumah Sakit."

Berdasarkan pemahaman tersebut, kita dapat menyimpulkan pengertian pasien ialah setiap orang yang memiliki gangguan kesehatan, baik psikologis, maupun organik. Pasien tidak dapat dibatasi hanya pada frasa "rumah sakit" karena apabila patokan seseorang dianggap sebagai pasien adalah rumah sakit, maka apabila ia sudah tidak menjalani tindakan medik di rumah sakit, misalnya rawat jalan, maka segala hak dan kewajibannya sebagai pasien akan hilang. Merujuk pada keterangan dari Kementerian Kesehatan mengenai Fasilitas Pelayanan Kesehatan (fasyankes) tersebut, salah satunya adalah di rumah sakit. Orang yang dirawat tentu saja disebut pasien. Maka, berdasarkan Pasal 32 huruf k UU Rumah Sakit, bahwa pasien memiliki hak untuk menolak pengobatan. Hak untuk menolak pengobatan ini sudah menjadi bagian mutlak bagi semua orang untuk memutuskan jenis tindakan medis apa yang akan dijalaninya. ${ }^{16}$

Sebelum melakukan sebuah bentuk pengobatan medis biasanya tenaga medis maupun lembaga terkait terlebih dahulu menyodorkan pasein untuk menandatangani surat pernyataan yang dalam dunia kedokteran disebut sebagai "Informed Concent" atau "Persetujuan Tindakan Medis"17. Persetujuan tindakan medis tersebut merupakan surat yang sangat penting untuk pihak tenaga kesehatan sebagai bukti bahwa pasien telah

\footnotetext{
${ }^{13}$ Zulhasmar, E. (2008). Ibid., h. 88.

${ }^{14}$ Kementerian Kesehatan Republik Indonesia. (2021). https://kesmas.kemkes.go.id/, diakses pada tanggal 25 Februari 2021.

${ }^{15}$ Zulhasmar, E. (2008). Ibid., h. 85.

16 Zulhasmar, E. (2008). Loc. Cit.

17 Zulhasmar, E. (2008). Loc. Cit.
} 
mengetahui segala informasi baik resiko ataupun hal lainnya yang timbul akibat tindakan medik yang akan dilakukan serta telah mendapat persetujuan dari pihak keluarga pasien. ${ }^{18}$ Selain pemberian persetujuan sebagaimana yang disebutkan sebelumnya, dalam kedokteran juga didapati adanya surat pernyataan "Penolakan Tindakan Medis" atau "Informed Refusal". Penolakan atas suatu tindakan medik ini adalah hak pasien yang berisikan penolakan terhadap suatu tindakan medik setelah mendapat informasi mengenai tindakan medik dari dokter. Penolakan terhadap tindakan medis ini pada hakekatnya merupakan hak yang dipunyai oleh setiap orang untuk menentukan jenis pengobatan seperti apa yang hendak dilakukan terhadap dirinya sendiri. ${ }^{19}$

Hak untuk menolak pengobatan ini bertolak belakang dengan peraturan yang telah dikeluarkan dalam Pasal 30 Perda DKI Jakarta no. 2 tahun 2020. Seperti yang telah disebutkan terlebih dahulu dalam penelitian ini bahwa hak untuk menolak pengobatan tersebut diatur di dalam undang-undang. Sedangkan pasal yang mengatur tentang pemberian sanksi atas penolakan vaksinasi tersebut diatur didalam Perda. Dalam sistem hukum Indonesia, kita mengenal beberapa jenis peraturan yang disusun dalam suatu tingkatan yang disebut sebagai hirarki perundang undangan. ${ }^{20}$ Sebagaimana tertuang dalam Pasal 7 UU No. 12 Tahun 2011 tentang Pembentukan Peraturan PerundangUndangan menyebutkan bahwa kedudukan undang-undang dalam hirarki lebih superior daripada peraturan daerah.

Menilik peraturan yang berkaitan dengan penolakan vaksin tersebut, sampai saat penelitian ini dilakukan tidak ditemukan adanya hukum di tingkat pusat yang secara spesifik dalam pasalnya mengatur mengenai sanksi penolakan vaksinasi tersebut. Adapun hukum pun hukum yang mengatur berkaitan dengan pemberian sanksi tersebut adalah Pasal 14 ayat (1) UU No. 4 Tahun 1984 tentang Wabah Penyakit Menular yang berbunyi "Barang siapa dengan sengaja menghalangi pelaksanaan penanggulangan wabah sebagaimana diatur dalam Undang-Undang ini, diancam dengan pidana penjara selama-lamanya 1 (satu) tahun dan/atau denda setinggi-tingginya Rp 1.000.000,- (satu juta rupiah)."

Lebih lanjut pada bagian penjelasan tidak terdapat pemahaman bahwa sengaja yang bagaimana yang dimaksud oleh undang-undang ini, serta apakah menolak vaksin termasuk kedalam menghalangi penanggulangan wabah. Penelitian ini dilakukan adalah dengan maksud apakah pemberian sanksi tersebut pantas diberlakukan. Sepanjang penelitian ini dilakukan berdasarkan kenyataan yang ada maka dapat ditarik kesimpulan bahwa hak untuk menolak pengobatan yang sejatinya merupakan hak asasi seseorang dapat dikesampingkan melalui pemberlakuan peraturan terkait. Selain itu dapat dilihat bahwa untuk memberikan sanksi terhadap penolakan tersebut dapat dikenakan sanksi yang bahkan lebih tinggi daripada sanksi sebagaimana tercantum/ditetapkan dalam peraturan yang lebih tinggi. Adapun hukum tingkat pusat, yang dimaksud adalah undang-undang, hanya menetapkan pemberian sanksi berupa denda paling besar adalah Rp. 1.000.000 (satu juta rupiah). Namun dalam peraturan yang tingkatannya lebih lemah daripada undang-undang, tepatnya peraturan daerah yang dimaksud adalah Perda DKI

18 Zulhasmar, E. (2008). Loc. Cit.

19 Zulhasmar, E. (2008). Loc. Cit.

20 Huda, N. M. (2006). "Kedudukan Peraturan Daerah Dalam Hierarki Peraturan PerundangUndangan". Jurnal Hukum Ius Quia IusTum, 13(1), 27-37, h. 29. 
Jakarta No. 2 tahun 2020 memberikan sanksi denda yang lebih tinggi daripada sanksi yang telah ditetapkan dalam Undang-undang sebagaimana telah disebutkan sebelumnya. Atas substansi dari pasal ini juga perlu mempertimbangkan bahwa terdapat ketentuan atau kriteria golongan masyarakat yang tidak dapat diberikan vaksin yang akan dibahas pada bagian berikutnya, sehingga penggunaan frasa "setiap" dalam hal ini dapat dibatasi hanya kepada golongan masyarakat yang memenuhi kriteria untuk divaksin.

\section{B. Analisis Penerapan Sanksi Ditinjau dari Pencerminan Nilai-Nilai Pancasila}

Hukum, membutuhkan moral, seperti ada istilah pada masa Kekaisaran Roma: "Quid Leges Sine Moribus?" yang berarti undang-undang tidak ada artinya kalau tidak dibarengi dengan moralitas. Oleh sebab itulah maka setiap aturan memerlukan norma moral sebagai tolak ukur. Di lain sisi, moral pun memerlukan hukum, moral hanyalah berupa abstrak kalau tidak diwujudkan dalam sebuah lembaga di masyarakat. ${ }^{21}$ Menurut Thomas Aquinas, keterikatan hati nurani dengan ketentuan hukum sangat erat, sehingga moral wajib menjadi tolak ukur untuk membentuk sebuah hukum yang adil. Dalam hukum tersebut harus mencerminkan moral bangsa yang dijadikan asas hukum tersebut. ${ }^{22}$

Asas dalam pembentukan hukum di Indonesia bersumber pada Pancasila. Sumber hukum Indonesia yaitu Pancasila dipertegas melalui Pasal 2 UU No. 10 Tahun 2004, dimana disebutkan bahwa "Pancasila merupakan sumber dari segala sumber hukum Negara." Disamping itu, ketentuan Pasal 3 ayat (1) menyebutkan juga "Undang Undang Dasar Negara Republik Indonesia Tahun 1945 merupakan hukum dasar dalam Peraturan Perundang-undangan". Pemahaman yang diberikan melalui pasal ini bahwa untuk menciptakan suatu peraturan perundang-undangan harus didasari oleh Pancasila yang merupakan dasar atau pedoman pembentukannya. Pancasila ialah cita atau tujuan hukum yang harus dicapai dalam setiap pembentukan hukum di Indonesia.

Cita hukum menurut Rudolf Stammler merupakan gagasan berpikir yang menjadi keharusan untuk mewujudkan hukum kepada hukum seperti apa yang diharapkan oleh masyarakat. Cita hukum tersebut menjadi penuntun untuk membantu tercapainya harapan masyarakat. Cita hukum juga memiliki dua perspektif, yaitu sebagai alat untuk menguji setiap hukum yang ada. Dilain sisi, ia juga berguna untuk menegaskan bahwa hukum harus disertai dengan saksi yang memaksa demi tercapainya keadilan. Keadilan menurut Stammler merupakan sebuah upaya dalam bentuk perbuatan yang diwujudkan untuk mencapai cita hukum. Oleh sebab itu menurut Stammler hukum yang adil (Richtgen Recht) adalah hukum yang orientasi tujuannya diarahkan kepada cita atau harapan masyarakat." 23

Negara Indonesia merupakan negara berbentuk kesatuan yang berlandaskan hukum sehingga segala sisi ataupun faktor yang ada dalam bermasyarakat wajib didasari kepada aturan yang berlaku. Segala kegiatan yang akan dan wajib dilakukan dalam kehidupan bernegara hanya dapat dijalankan apabila terdapat aturan yang mengatur

${ }^{21}$ Bertens, K. (2004). Etika, Jakarta: Gramedia Pustaka Utama, h. 41.

22 Rosadi, O. (2010). "Hukum Kodrat, Pancasila dan Asas Hukum dalam Pembentukan Hukum di Indonesia". Jurnal Dinamika Hukum, 10(3), 282-290, h. 283.

${ }^{23}$ Herlina, N. (2018). "Cita Hukum Pancasila Dapat Berkembang dalam Batang Tubuh UndangUndang Dasar Republik Indonesia 1945". Lex Librum: Jurnal Ilmu Hukum, 4(2), 673-679, h. 676. 
pelaksanaannya. Berkaitan dengan hal tersebut maka hukum menjadi penyaring bagi konsep dan sistem tersebut agar terwujudnya tujuan yang dicita-citakan. ${ }^{24}$ Dari sinilah kita bisa melihat bahwa Pancasila merupakan poin penting bahkan merupakan aspek keharusan dalam pembangunan hukum di Indonesia. Semua jenis peraturan yang hendak diwujudkan dalam peraturan tertulis sebelumnya wajib disaring terlebih dahulu dengan nilai nilai luhur yang ada didalam Pancasila. Sebagaimana telah kita ketahui bahwa kelima sila tersebutlah yang menjadi dasar atau pedoman dalam pembentukan peraturan perudang-undangan. Seperti dalam hukum Indonesia kita mengenal istilah "lex superior derogate legi inferior" yang diartikan peraturan dengan posisi dalam hirarkinya lebih rendah tak diperbolehkan sedikitpun melawan peraturan yang posisinya lebih tinggi. 25

Segala penyelenggaraan pembentukan hukum berdasarkan Pancasila. Pancasila memiliki lima nilai dasar, yaitu: "1) Nilai Ketuhanan; 2) Nilai Kemanusiaan; 3) Nilai Persatuan; 4) Nilai Kerakyatan; 5) Nilai Keadilan." 26 Sila ke-dua Pancasila dimana menyatakan "Kemanusiaan yang adil dan beradab" merupakan pencerminan ataupun perwujudan bahwa Indonesia mengakui adanya HAM. Sila ini menunjukkan bahwa adanya penghargaan, toleransi, pengakuan, kesetaraan, serta tidak adanya diskriminasi antar agama, suku, ras, dan gender. Adanya penekanan pada sila ke-dua bahwa nilai kemanusiaan itu adil serta beradab. Tipe keadilan sebagaimana dimaksudkan didalam Pancasila adalah memperlakukan semua orang secara adil dan beradab sebagaimana yang menjadi hak asasi yang dimilikinya. HAM merupakan hak yang sudah ada pada diri tiap orang semenjak ia berada di perut ibunya. HAM pada hakekatnya selalu di cover oleh hukum karena hukum memang diciptakan dengan tujuan melindungi masyarakat. HAM juga memberikan jaminan atas kedudukan yang sama bagi tiap orang, baik dihadapan hukum maupun pemerintahan. Selain memanusiakan manusia, keadilan dalam Pancasila juga sebaaimana terdapat pada sila ke-lima dimana disebutkan "Keadilan sosial bagi seluruh rakyat Indonesia". Manusia merupakan mahkluk memerlukan kehadiran orang lain, oleh karena itu sesuai dengan ajaran Agustinus, maka kita setiap orang harus saling toleransi dan saling menghormati mengenai nilai-nilai seperti "harga dan cinta, dan mengasihi sesama." 27

Cita hukum ("rechtsidee") memiliki keadilan sebagai tujuan yang hendak dicapai. Keadilan yang dimaksud didalam hukum tidak sama dengan "keadilan sosial" yang terkandung pada Pancasila maupun keadilan "kemanusiaan yang adil dan beradab." Dalam keadilan yang berlandaskan Pancasila, adalah sebuah kewajiban bagi seseorang dalam hubungannya dengan seorang lainnya dalam bermasyarakat. Keadilan sosial yang terdapat didalam Pancasila adalah sebuah sumber nilai yang masih perlu disederhanakan menjadi keadilan hukum. Dari tujuan untuk mewujudkan keadilan tersebut maka lahirlah sebuah konsep keadilan yang merupakan hasil dari pencerminan serta

24 Rahardjo, S. (2009). "Pendidikan Hukum Sebagai Pendidikan Manusia". Law Reform, 1(1), 1-10., h. 5 .

${ }^{25}$ Pahlevi, F. S. (2016). “Revitalisasi Pancasila Dalam Penegakan Hukum Yang Berkeadilan Di Indonesia". Justicia Islamica, 3(2), 1-15., h. 3.

26 Pahlevi, F. S. (2016). Loc.Cit.

${ }^{27}$ Febriansyah, F. I. (2017). “Keadilan Berdasarkan Pancasila Sebagai Dasar Filosofis dan Ideologis Bangsa". DiH: Jurnal Ilmu Hukum, 13(25), 1-27, h. 9. 
pemberlakuan dari asas pembentukan hukum. Keadilan seperti ini biasa disebut sebagai "Keadilan Prosedural" atau "Procedural Justice". Oleh karena itu dalam hukum sering kita jumpai lambang lambang seperti pedang, timbangan, dan lain lain untuk memberikan jaminan kepastian hukum yang tidak memihak dan tidak melihat latar belakang dari seseorang. ${ }^{28}$

Pembentukan sebuah produk hukum, yang harus menjadi sumber dari hukum tersebut adalah Pancasila. Oleh sebab itu, manusia yang merupakan makhluk sosial yang membutuhkan keadilan harus merupakan aspek penting dalam membentuk suatu produk hukum. Indonesia sebagaimana merupakan Negara yang berlandaskan Pancasila, memandang penting hak kemanusiaan sebagaimana tercantum pada Pancasila sila ke-2, yang menyebutkan "Kemanusiaan yang adil dan beradab" dimana memposisikan tiap individu sesuai dengan kodrat, harkat dan martabatnya. Dengan ini maka dapat dilihat bahwa bangsa Indonesia mengakui adanya Hak Asasi Manusia serta kebebasan yang bertanggungjawab setiap manusia sebagai hak yang pada hakekatnya ada dan tak boleh diambil dari diri manusia dan wajib mendapatkan perlindungan hukum, dihormati dan ditegakkan agar tidak ada diskriminasi, serta untuk meningkatkan rasa kemanusiaan, meningkatkan kecerdasan, menciptakan kesejahteraan dan menumbuhkan kebahagiaan serta keadilan ditengah masyarakat. ${ }^{29}$

Penerapan sila "Kemanusiaan yang adil dan beradab" ditunjukkan dalam pernyataan-pernyataan, contohnya yaitu Negara Indonesia mengakui adanya hak bagi setiap orang untuk menentukan nasibnya masing-masing, Indonesia sebagai bangsa yang berbudaya tinggi tidak mentolerir adanya perlakuan sewenang-wenang antar sesama manusia, negara juga mengakui atas persamaan derajat setiap orang, kesetaraan dimata hukum maupun pemerintahan serta kewajiban untuk menaati setiap peraturan yang berlaku. ${ }^{30}$ Sebagaimana disebutkan kewenangan dalam menentukan nasibnya, didalamnya terdapat juga hak untuk menentukan bagaimana pengobatan yang ingin ia dapatkan. Sebagaimana telah diatur mengenai hak pasien untuk menolak pengobatan. Tidak boleh ada seorang pun yang dapat mencabut hak tersebut dari diri tiap orang, termasuk juga tidak dapat dikesampingkan oleh adanya peraturan daerah tersebut. Sebagaimana telah kita pelajari bahwa pancasila ialah landasan maupun pedoman dalam merancang sebuah perundang undangan. Berdasarkan penelitian, aturan mengenai sanksi tersebut belum mencerminkan dari nilai luhur yang terkandung didalam pancasila, khususnya nilai kemanusiaan.

Sebagai pertimbangan keadilan yang berdasarkan kemanusiaan, perlu adanya sudut pandang dari sisi lainnya. Sebagaimana bersumber dari covid19.go.id, terdapat beberapa kriteria orang yang tidak dapat menerima vaksin, yaitu "Memiliki riwayat konfirmasi Covid-19; Wanita hamil dan menyusui; Berusia di bawah 18 tahun; Tekanan darah di atas 140/90; Mengalami gejala ISPA seperti batuk/pilek/sesak napas dalam 7 hari terakhir; Ada anggota keluarga serumah yang kontak erat/suspek/konfirmasi/sedang dalam perawatan karena penyakit Covid-19; Sedang mendapatkan terapi aktif jangka panjang terhadap penyakit kelainan darah; Menderita penyakit jantung (gagal jantung/penyakit

\footnotetext{
28 Febriansyah, F. I. (2017). Loc. Cit.

${ }^{29}$ Febriansyah, F. I. (2017). Ibid., h. 10-11.

${ }^{30}$ Febriansyah, F. I. (2017). Ibid., h. 12
} 
jantung koroner); Menderita penyakit Autoimun Sistemik (SLE/Lupus/, Sjogren, vaskulitis, dan autoimun lainnya); Menderita penyakit ginjal; Menderita penyakit Reumatik Autoimun/Rhematoid Arthritis; Menderita penyakit saluran pencernaan kronis; Menderita penyakit Hipertiroid/hipotiroid karena autoimun; Menderita penyakit kanker, kelainan darah, imunokompromais/defisiensi imun, dan penerima produk darah/transfusi; Menderita penyakit Diabetes Melitus (dalam kondisi tertentu bisa diberikan vaksin Covid-19); Menderita HIV (dalam kondisi tertentu bisa diberikan vaksin Covid-19); dan Memiliki penyakit paru sepertu asma, PPOK, TBC (dalam kondisi tertentu bisa diberikan vaksin Covid-19)". Terhadap beberapa kriteria ini juga memiliki hak yang sama sebagaimana dijamin didalam UUD NRI 1945 pasal $28 \mathrm{H}$ ayat 1 yang pada intinya yakni hak setiap orang untuk memperoleh lingkungan hidup yang sehat, termasuk bebas dari virus Covid-19. Oleh sebab itu terdapat dua kepentingan dalam hal ini hak untuk menolak pengobatan, serta hak untuk mendapatkan lingkungan yang bebas dari virus Covid-19.

Perlu ditekankan bahwa kewajiban vaksin dari segi kesehatan serta kepentingan masyarakat umum memang diperlukan demi menghambat, memutus atau bahkan menghentikan perkembangan wabah virus tersebut. Namun yang perlu diperhatikan apakah pemberian sanksi tersebut sudah memenuhi berbagai aspek pembentukan hukum di Indonesia atau belum. Bahwa keadilan menurut peraturan di Indonesia merupakan keadilan yang humanistik berdasarkan pancasila. Keadilan dimana harkat dan martabat seseorang dijunjung tinggi. Dalam pengakuan hak tersebut pula dibarengi dengan kewajiban. Kewajiban yang dimaksud adalah kewajiban untuk menghormati, menghargai serta pengakuan hak yang sama yang dimiliki oleh setiap orang. ${ }^{31}$ Dalam UU Rumah Sakit sudah sangat jelas diatur bahwa seseorang berhak untuk menolak pengobatan. Seseorang berhak memilih mengenai jenis pengobatan seperti apa yang ingin ia jalani. Penggunan kata "setiap" dalam Pasal 30 Perda DKI Jakarta No. 2 tahun 2020 tersebut tidak memberikan batasan apakah seseorang yang menolak vaksin tersebut adalah seseorang yang terjangkit virus tersebut atau bukan.

Penggunaan kata "setiap", berarti bagi semua orang yang dikategorikan sebagai penerima vaksin, maka sanksi tersebut tetap berlaku. Maka kita dapat melihat bagaimana asas keadilan dan kemanusiaan yang dimaksud dalam perda tersebut. Pertentangan diantara perundang undangan tersebut yang kemudian menjadi kerancuan, ketidak jelasan serta menimbulkan ketidakpastian hukum bagi masyarakat. Belum terpenuhinya asas serta pemberian sanksi yang tidak mencerminkan nilai luhur yang terdapat pada pancasila tersebut dapat dijadikan pembahasan yang menarik untuk dikaji ditengah situasi pandemi ini. Berdasarkan pembahasan ini, kita bisa menilai bahwa penerapan sanksi tersebut tidak berdasarkan asas kemanusiaan, dan keadilan. Pemberian sanksi yang tidak masuk akal ini akan menimbulkan isu-isu, berita tidak baik, hoax, serta perbincangan ditengah masyarakat bahwa situasi pandemi dengan keadaan ekonomi yang melemah ini justru dijadikan ladang bisnis untuk meraup keuntungan dari masyarakat dengan melihat celah-celah hukum seperti apa yang dapat diterapkan.

\section{PENUTUP}

${ }^{31}$ Kristiyanti, C. T. S. (2017). "Penguatan Manifestasi Nilai Keadilan Pancasila dalam Penegakan Hukum di Era Kontemporer". Justitia Et Pax, 33(1), 1-20, h. 14. 
Terdapat beberapa poin penting setelah memahami topik kajian dalam pembahasan penelitian yang dapat disimpulkan secara singkat sebagai berikut. Hak untuk menolak pengobatan atau tindakan medik adalah hak asasi bagi semua orang tanpa terkecuali. Ini merupakan hak yang tidak boleh dibatasi oleh siapapun, termasuk juga tidak boleh dikesampingkan melalui peraturan daerah. Setiap orang memiliki kewajiban, yaitu menghormati, menghargai serta pengakuan akan hak yang sama yang dimiliki oleh semua orang dan wajib menjunjung tinggi hak tersebut. Bahwa penerapan sanksi yang diatur didalam perda yang telah disebutkan diatas telah melanggar hak asasi manusia. Sebagaimana telah diuraikan didalam penelitian ini bahwa terdapat pertentangan diantara perundang undangan itu sendiri. Perda tersebut berlawanan dengan hak yang telah diatur didalam undang undang. Dalam pembentukan hukum di Indonesia kita mengenal hirarki perundang udangan dimana hukum yang berada pada posisi hirarkinya dibawah, sedikitpun tak diijinkan untuk berlawanan dengan hukum yang berada diatas posisinya. Dalam hal ini bahwa kedudukan perda dalam hirarki perundang undangan di Indonesia letaknya berada di bawah undang undang. hal ini membuktikan bahwa terdapat kerancuan maupun ketidak pastian hukum yang membuat masyarakat, khususnya warga DKI Jakarta bingung untuk memilih hukum yang mana yang harus ditaati. Di satu sisi diatur mengenai hak dengan hirarki yang lebih tinggi, namun di sisi lainnya terdapat aturan atau pemberian sanksi apabila tidak mematuhi hukum yang telah datur di dalam perda tersebut. Pemberlakuan sanksi tersebut tidak mencerminkan aspek aspek yang ada didalam Pancasila. Sebagaimana kita telah mengetahui bahwa Pancasila adalah landasan atau pedoman dalam membentuk suatu peraturan. Pancasila menjadi cita hukum atau tujuan dari pembentukan sebuah produk hukum. Nilai nilai yang ada dalam Pancasila tersebut harus terpenuhi dalam setiap pembentukan hukum. Sehingga dapat dilihat bahwa penerapan sanksi tersebut belum memenuhi nilai "kemanusiaan" dan "keadilan" yang terdapat pada Pancasila sebagai dasar pembentukan peraturan. Penegakan hukum, termasuk pemberian sanksinya senantiasa perlu menanamkan nilai Pancasila didalamnya.

Untuk menghapuskan kerancuan, serta memberikan kepastian hukum, khususnya bagi warga DKI Jakarta, maka harus dilakukan Peninjauan Kembali (PK) terhadap pemberlakuan sanksi tersebut yang diatur didalam Perda DKI Jakarta No. 2 tahun 2020. Untuk menciptakan ketertiban, ketenteraman, serta masyarakat yang patuh hukum, maka diperlukan hukum yang jelas pula. Oleh karena itu, diantara perundang undangan tersebut tidak boleh ada pertentangan antara peraturan satu dengan peraturan lainnya. Peraturan tidak dapat mengesampingkan hak asasi dari manusia. Hak asasi tersebut harus tetap dijunjung tinggi, sebagai bukti bahwa Indonesia mengakui adanya HAM dan kesetaraan derajat setiap manusia.

\section{DAFTAR PUSTAKA}

Appludnopsanji, A., \& Disemadi, H. S. (2020). Problematika Kebijakan Pembebasan Narapidana sebagai Upaya Penanggulangan COVID-19 di Indonesia. Jurnal Wawasan Yuridika, 4(2), 131-148.

Arifin, R., \& Lestari, L. E. (2019). Penegakan dan Perlindungan Hak Asasi Manusia di Indonesia dalam Konteks Implementasi Sila Kemanusiaan yang Adil dan Beradab. Jurnal Komunikasi Hukum (JKH), 5(2), 12-25. 
Bertens, K. (2004). Etika, Jakarta: Gramedia Pustaka Utama.

Disemadi, H. S., \& Handika, D. O. (2020). Community Compliance With The Covid-19 Protocol Hygiene Policy in Klaten Regency, Indonesia. Legality: Jurnal Ilmiah Hukum, 28(2), 121-133.

Febriansyah, F. I. (2017). Keadilan Berdasarkan Pancasila Sebagai Dasar Filosofis dan Ideologis Bangsa. DiH: Jurnal Ilmu Hukum, 13(25), 1-27.

Fransisco, W. (2020). Interaktif Masyarakat Terhadap Hukum Dalam Kehidupan Normal Baru Pasca COVID-19. Journal of Judicial Review, 22(2), 151-164.

Herlina, N. (2018). Cita Hukum Pancasila Dapat Berkembang dalam Batang Tubuh Undang-Undang Dasar Republik Indonesia 1945. Lex Librum: Jurnal Ilmu Hukum, 4(2), 673-679.

Huda, N. M. (2006). Kedudukan Peraturan Daerah Dalam Hierarki Peraturan PerundangUndangan. Jurnal Hukum Ius Quia IusTum, 13(1), 27-37.

Kang, C., \& Disemadi, H. S. (2021). The COVID-19 Pandemic Outbreak Impact And Prevention From Legal Perspective: An Indonesian Experience. In CoMBInESConference on Management, Business, Innovation, Education and Social Sciences. 1(1), 134144).

Kementerian Kesehatan Republik Indonesia. (2021). https://kesmas.kemkes.go.id/, diakses pada tanggal 25 Februari 2021.

Kristiyanti, C. T. S. (2017). Penguatan Manifestasi Nilai Keadilan Pancasila dalam Penegakan Hukum di Era Kontemporer. Justitia Et Pax, 33(1), 1-20.

Masnun, M. A., Sulistyowati, E., \& Ronaboyd, I. (2021). Pelindungan Hukum Atas Vaksin Covid-19 Dan Tanggung Jawab Negara Pemenuhan Vaksin Dalam Mewujudkan Negara Kesejahteraan. DiH: Jurnal Ilmu Hukum, 17(1), 35-47.

Pahlevi, F. S. (2016). Revitalisasi Pancasila dalam Penegakan Hukum yang Berkeadilan di Indonesia. Justicia Islamica, 3(2), 1-15.

Rahardjo, S. (2009). Pendidikan Hukum Sebagai Pendidikan Manusia. Law Reform, 1(1), 110.

Rosadi, O. (2010). Hukum Kodrat, Pancasila dan Asas Hukum dalam Pembentukan Hukum di Indonesia. Jurnal Dinamika Hukum, 10(3), 282-290.

Sari, M. K. (2020). Sosialisasi Tentang Pencegahan Covid-19 di Kalangan Siswa Sekolah Dasar di SD Minggiran 2 Kecamatan Papar Kabupaten Kediri. Jurnal Karya Abdi Masyarakat, 4(1), 80-83.

Zulhasmar, E. (2008). Implikasi Hukum Penolakan Tindakan Medik. Lex Jurnalica Vol. 5 No. 2, 2008, 83-111. 